\title{
On Experiential English Language Teaching Model and Implementation Approaches
}

\author{
Lijing Diao ${ }^{1}$ Chunhui Pan ${ }^{2}$ \\ ${ }^{1}$ English Department, Cangzhou Normal University, Cangzhou 061001, Hebei, China \\ ${ }^{2}$ Chemistry Department, Cangzhou Normal University, Cangzhou 061001, Hebei, China
}

\begin{abstract}
The experimental English language teaching model emphasizes to enable the students to perceive, understand, comprehend, and verify the teaching content in a real or virtual environment. This paper analyzes the theoretical basis of the experimental English language teaching model and investigates its implementation approaches.
\end{abstract}

Keywords: Experimental English Language Teaching; theoretical basis; implementation approach

\section{Introduction}

The traditional English language teaching model is teacher-centered, emphasizes the teaching of vocabulary and grammar and ignores the interaction and mutual relationship of subject and object. In recent years, many domestic experts and scholars have begun to study the experimental English language teaching model. However, it is still in the stage of concept understanding. This paper probes into the theoretical basis of the experimental English language teaching model and its means of implementation at college.
2. The theoretical basis of the experimental English language teaching model

The experimental English language teaching model is a new teaching theory formed in the 1970s under the influence of communicative teaching theory and task-based teaching theory, which emphasizes the participation and practicality of the learners. Its theoretical basis is constructivism, which believes that learning is an active process of constructing. It is student-centered and emphasizes students are the cognitive subjects. Piaget believes that the formation and development of knowledge is a process of constructing, in which learners take advantage of the surrounding environment and the necessary learning resources to develop their own knowledge systems through the interaction of the new experience and the original knowledge and experience with the help of others. The experiential teaching theory puts emphasis on process, and is practice-oriented. Therefore, the experience of experience, especially the experience of direct experience is the core of the whole experimental learning mode. From the viewpoint of constructivism, college English teaching in China lacks the interaction between subject (student) and objects 
(environment) and the process of learners actively constructing.

David Kolb (American social psychologist) proposed the most systematic experiential learning model in $1984^{[1]}$. He believes that experiential learning is a circle. Each circle is divided into four stages: concrete experience, reflective observation, abstract conceptualization, active experimentation. The four aspects of the circle cycle, spiral, and deepen. Specific experience is the basis of observation and reflection. The observed things are assimilated into a new understanding or theory by deductive reasoning and form an abstract concept. These abstract theory or understanding will guide the new experience and practice, and thus form a new circle. Experiential teaching is to simulate or create a scenario in the teaching process, and the students complete the four stages of the experiential learning model under the guidance of the teacher and move forward in circles unceasingly.

English is a communication tool and the effective way to college English Learning is to learn and use at the same time, which is in line with the characteristics of experiential learning. David Nunan pointed out that the change which has a profound impact on all aspects of teaching philosophy is the one from knowledge teaching model to experiential model ${ }^{[2]}$.

Currently, many college English teaching materials are arranged by theme. Each unit has a particular theme and the teaching content, including language knowledge and background knowledge, reading material, hearing is designed and arranged around the theme. When a teacher designs a variety of teaching and learning activities to complete the teaching tasks, he should ensure the students have enough opportunities to experience, perceive and think the new content. This is actually the previous two ways in Kolb model: specific experience and reflective observation. And then, under the guidance of teachers students are supposed to generalize the content observed and draw new concepts (new grammar, language knowledge or background knowledge) and apply them into the new context. This is actually the latter two in Kolb mode: abstract conceptualization, active experimentation. Kolb reminds us that the high-level cognition, innovation and personal development need more interaction between the four aspects of the learning model. If the contents of a unit are finished 1 in accordance with the cycle of this model, students should be able to not only perceive the content of the topic of the unit, but also use it in the new context.

\section{The implementation approaches of the experimental English teaching model}

\subsection{Situational Experimental English Language Teaching}

Here we can use Lesson 5 in New Horizon College English Book 1 as an example to illustrate the application of the experiential English teaching model. The theme of this unit is AIDS and the articles are about human fighting against AIDS. It is just before World AIDS Day that students learn this article. At that time there are many reports related to the topic and students are interested in the text. At the beginning of the class we can ask the students what they have read about AIDS and if they know the theme of World AIDS Day this year. This helps students combine the text content with their real life, which can not only enhance the practicality of classroom teaching, but also stimulate the interest of students to participate in learning. Then we can take advantage of the multimedia to playback AIDS-related courseware prepared before 
class, which can be some of the fragments from the television, feature films, documentaries, and music films and be used to show the English language situations and language application method through multimedia. On one hand, students can have the opportunity to experience and think about the new content so that they can have sufficient language input and absorb useful language materials around the theme. On the other hand, these materials can be used to activate students' cognitive and emotional areas so as to deepen the knowledge. While reading the article, teachers can let students summarize the content in their own words and then ask questions for students to discuss to deepen their understanding of the article. After the explanation of the text we can ask students to use the key words and expressions to retell the text in detail. In teaching process there are a variety of ways to strengthen the students' autonomy and their communicative ability, such as role-playing, various forms of conversations, symposia, coherent dialogue, composition, oral or written translation. Through a series of communicative tasks and activities students can make good use of AIDSrelated topics in a new context. As a follow-up activity, students can view information about AIDS and HIV virus, Louganis and more information on the internet. The design of this activity is to cultivate students' comprehensive ability to apply knowledge. The so-called application ability is not only to use foreign languages in the life but also use this skill to collect information. We should pay attention to develop this skill in our foreign language teaching process ${ }^{[3]}$ Through the cycle process the students get exercise in vocabulary application, sentence translation, oral expression. The students felt that compared to the lecturing method this kind of classroom teaching can arouse the learning enthusiasm and initiation and the learning effect is relatively good.

\subsection{Social Practice Experimental English Language Teaching}

With the increase of social needs of English talents and the popularity of the school-enterprise cooperation, corporations have become the practical place of school talents. The school can arrange for students to practice in the diplomatic process, and learn how to use their English knowledge to settle the real problems. In this kind of teaching process, students can experience the normal application of English and the English application customary rather than simply learn English knowledge. In addition, the social practice experiential English teaching can develop students' English comprehensive application ability including listening, reading and writing, broaden their horizons, which can provide a good social experience for students to work after graduation and improve their competitive ability

\subsection{Role Reversal Experimental English Language Teaching}

In traditional English teaching classroom teachers are knowledge disseminators and students play the role of the knowledge receiving. In the process students have been in a passive position. However, Role Reversal Experimental English Language Teaching has been adopted by more and more teachers. In this teaching model the roles are reversed. Students explain the English knowledge on the podium while teachers listen. In this process the relationship between teachers and students is closer and students can also research knowledge points more deeply, exercise their courage, and experience teachers' hard work, which can have an 
active effect on their English learning afterwards.

\subsection{Multimedia Experiential English Language Teaching}

With the high-tech continuously applied to teaching, especially the popularity of multimedia has brought a lot of convenience to modern teaching. In Multimedia Experiential English Language Teaching teachers use multimedia technology to provide students with high-quality audio-visual conditions, which allow students to experience English learning effectively and completely. Due to the limited resources and hardware facilities at college, multimedia has become the main way of experimental teaching. Teachers can play animated images in situational dialogues to attract students' attention. While teaching knowledge point, the teacher can also play foreign real videos, which allow students to feel to be on the scene personally and make up for the defects that students can't come into contact with English-speaking

\section{Conclusion}

The application of Experimental English Language teaching is not long and hasn't formed a complete teaching theory, concept and model. There are still a variety of obstacles and challenges in the application process, but it is in line with the significance of constructivism cognitive rules. Its role is bound to show up in the English teaching application and will be of a great role in promoting English teaching.

\section{References}

[1] David Kolb. The Theory of Experiential Learning and ESL. The Internet TESL Journal. Vol. III, No. 9, September 1997.8

[2] Nunan, D. Second Language

Teaching and Learning. Foreign

Language Teaching and Research

Press \& Heinle\& Heinele/Thomson Learning Asia. 2001.

[3] Kong Qingyan, Hu Zhuanglin, GUI Shichun, Jia Guodong, pay attention to " University experience English ", " Chinese University Education " eighth period. 2003. 